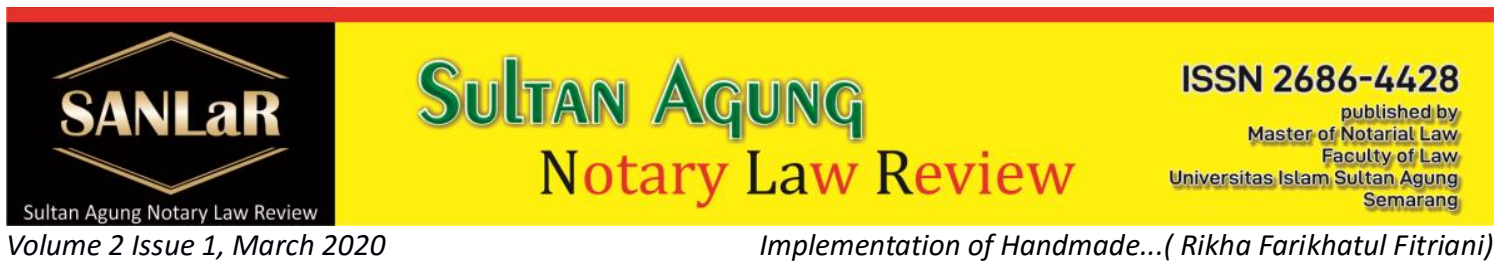

\title{
Implementation of Handmade Credit Agreements (Without Notary Deed)
}

\author{
Rikha Farikhatul Fitriani ${ }^{*}$ and Taufan Fajar Riyanto ${ }^{* *}$ \\ *) Bank Jateng employees, email: rikhafarikhatul@gmail.com \\ ${ }^{* *}$ Notary / Land Deed Making Official in Semarang Regency
}

\begin{abstract}
This research aims to find out and analyze the credit implementation process made under hand (without a Notary deed) at PT. Regional Development Bank of Central Java, Semarang Regional Deposit Assistant branch and to identify and analyze inhibiting factors in the implementation of loans made under hand (without a Notary deed) and how to overcome them. This study uses an empirical juridical approach, which is a legal research carried out by examining and analyzing existing facts in line with observations in the field. Central Java Regional Development Bank, Semarang Regional Deposit of Sub-Branch, for credit application will be given a Loan Application Certificate (SKPP) to be filled in completely and accompanied by the required documents / letters. The credit process "officially" begins with the submission of the completed form. Completely and correctly, all received credit applications will be analyzed and evaluated for credit. Guarantee transactions are carried out to conduct checks and research. The results of the analysis and evaluation, the transaction officer will report to the credit provider officer to refuse credit. Based on the results of the guarantee transaction, the credit provider officer analyzes the credit and the conclusion from the analysis is the adequacy of the guarantee, and for credit decisions accepted. Constraints that occur in the implementation of loans made underhand at PT. The Central Java Regional Development Bank for the Sub-Branch of the Semarang Region Regional Deposit to the community is largely a factor in providing credit guarantees in the form of land certificates of ownership rights (SHM) or Building Use Rights (SHGB) certificates that must be owned by prospective debtors themselves. Many prospective debtors have land assets that are still in the form of meters $C$ and meters $D$ so that the land cannot be pledged as collateral for credit. Settlement in overcoming constraints in implementing credit for PT. Bank Central Java Regional Deposit of Sub-Branch Offices are carried out by means of Bank officers assisting the management of the Property Rights Certificate to the National Land Agency (BPN) and continuing to provide outreach to candidates when customers apply for credit, while efforts to overcome the Bank's efforts to resolve bad loans this is the debtor in default, the Bank may first settle by way of kinship or by way of deliberation, if this fails, the Bank may issue a warning letter or warning letter in the form of administrative sanctions.
\end{abstract}

Keywords: Credit; Agreements; Notary Deed.

\section{Introduction}

Increasing economic growth in the State of Indonesia, raises public awareness to improve their standard of living as social people. The community also does not escape thinking about future investment as the hope of their future life, especially with the current increase in economic growth. Efforts to find good investments in the future also require large capital. It cannot be denied that the effort to obtain such capital is not far from the name of a Bank financial institution. Bank is a legal entity engaged in financial 
services, which can collect funds from the public directly and channel them back to the community through credit legal institutions. ${ }^{1}$.

The meaning of non-bank financial institutions can be seen in Article 1 number (1) of the Presidential Regulation of the Republic of Indonesia Number 9 of 2009 concerning Financing Institutions. "Financing institutions are business entities that carry out financing activities in the form of provision of funds or capital goods". Non-Bank Financial Institutions, namely business entities that carry out activities in the financial sector that directly or indirectly collect funds by collecting securities and channeling them to the community to finance company investments. ${ }^{2}$ Indonesian banking aims to support the implementation of national development in order to increase equity, economic growth and national stability towards increasing the welfare of the people at large..$^{3}$

Providing credit by the Bank makes it easier for the public to obtain funding. Regarding further explanation regarding credit, it is explained in the Banking Law in Article 1 Point 10 which reads: 4 "Credit is the provision of money or an equivalent claim, based on a loan agreement between the Bank and another party, which requires the borrower to pay off its debt after a certain period of time with interest.

In the framework of granting credit, before the credit application is granted, the Bank must pay attention to matters relating to the condition of the prospective customer (debtor) who wishes to apply for credit, where the Bank has a formula that is generally used in the selection of prospective customers, namely The Five C's of Credit. The analysis consists of Character (personality), Capacity (ability), Capital (wealth), Collateral and Condition of Economy. After the process of analyzing the credit application is complete and fulfills the requirements proposed by the Bank, it is signed by both parties, then a search or realization of credit is carried out, which time is determined by the Bank. ${ }^{5}$

The various types of agreements stipulated in books V to XVIII books III of the Civil Code do not contain provisions regarding bank credit agreements. Even in Act Number 10 of 1998 concerning Banking itself does not recognize the term Bank credit agreement. This term is contained in government instructions addressed to the Bank community. It is instructed that in the provision of credit in any form the Bank is required to use a credit agreement contract. ${ }^{6}$

\footnotetext{
${ }^{1}$ Sembiring, Sentosa. (2012). Hukum Perbankan. Jakarta: CV. Mandar Maju. p.18

2 Fuady, Munir. 2002. Hukum Tentang Pembiayaan Dalam Teori dan Praktek. Bandung: Citra Aditya Bakti. p. 200

${ }^{3}$ Rachmawati, Noor., \& Hanim, Lathifah. (2018). Notary Role in The Establishment of Foreign Investment Limited Company Based on The Act No. 25 Of 2007 on Investment in Semarang.JURNAL AKTA: Vol. 5, No. 4, 965-974.Retrieved from http://jurnal.unissula.ac.id/index.php/akta/article/view/3939

${ }^{4}$ Ignatius Ridwan Widyadharma, 1995, Hukum Perbankan, CV Ananta, Semarang, p. 12.

5 Ibid, p.14.

${ }^{6}$ Aman, Mgs. Edy. J. (1989). Kredit Perbankan Suatu Tinjauan Yuridis. Yogyakarta: Liberty. p. 30
} 
According to Marhainis Abdul Hay, ${ }^{7}$ states that the provisions of Article 1754 of the Civil Code concerning lending and borrowing provisions are identical to the Bank credit agreement. Furthermore, in Article 1754 it is stated that "A loan-replacement agreement is an agreement whereby one party gives the other party a certain amount of goods which are used up due to use on the condition that the latter will return the same amount of the same kind and condition". Wirdjono Prodjodkoro ${ }^{8}$, Interpret the provisions of Article 1754 of the Civil Code as a real agreement. Because Article 1754 does not state that the 1st party is bound to provide a certain amount of goods which are used up, but rather that the 1st party gives a certain amount of goods which are used up.

Meanwhile, Mariam Darus Badrulzaman ${ }^{9}$, believes that the Bank's credit agreement is a preliminary agreement (vooroverensoms) of the delivery of money. This preliminary agreement is the result of an agreement between the giver and recipient of the agreement regarding the legal relationship between the two. This agreement is consensual in nature (facto de contrahendo) which is controlled by Law Number 10 of 1998 concerning Banking and the general section of the Civil Code. The delivery of the money itself is real. When the money is delivered, the terms set forth in the credit agreement model for both parties apply. Thus it is clear that it is not enough to know the nature of a bank credit agreement just to look at the Civil Code and Act Number 10 of 1998 concerning Banking.

In banking practice in general, credit agreements have generally been made in a standard or written form in the form of a blank. The form is given to each credit applicant whose contents are not discussed but after being read by the applicant, the Bank only asks for the opinion of the customer whether or not they can accept the terms stated in the form, while the blank things in the credit agreement are the size of the loan. , the amount of interest, the credit period and the objectives are things that cannot be filled in without the agreement of both parties. The contents of a predetermined credit agreement in a certain form that has been booked show us that the credit agreement in banking practice is a standard agreement. This standard agreement by Mr. A. Pittlo is also called the adhes agreement, while by Mariam Darus Badrulzaman ${ }^{10}$, translated by the term standard agreement.

A standard agreement is an agreement whose contents are standardized and set forth in the form of a form, and the weakness of this standard agreement is regarding the nature, because it is determined unilaterally and therein a number of clauses that exempt credit from its obligations (exoneration clause) are determined. At least while the regulations regarding this standard agreement have not been issued, this standard agreement needs to be supervised by the government.

\footnotetext{
${ }^{7}$ Hay, Marhainis Abdul. (1979). Hukum Perbankan Di Indonesia. Jakarta: Pradnya Paramita. p. 147

8 Prodjodkoro, Wirdjono. (1981). Pokok-pokok Hukum Perdata Tentang Persetujuan-persetujuan Tertentu. Bandung: Sunan Gunungjati. p. 137

9 Badrulzaman, Mariam Darus. (1983). Perjanjian Kredit Bank. Bandung: Alumni. p. 28

${ }^{10}$ Badrulzaman, Mariam Darus. (1994). Aneka Hukum Bisnis. Bandung: Alumni. p. 35
} 
The government, in this case Central Java Province, has taken action to accelerate the implementation of regional development, namely by establishing a commercial bank institution. At the beginning of its establishment, the Central Java Bank was named the Central Java Regional Development Bank. However, in line with the times the Central Java Regional Development Bank changed its name to a Limited Liability Company (PT. Persero Jawa Tengah). Ownership status of PT. Central Java Bank is adjusted to the percentage of shares that are invested in the Bank. In connection with the Central Java Provincial government as the largest shareholder, PT. Central Java Bank as the owner, so that the status of PT. Central Java Bank as a regional owned business.

PT. The Central Java Bank was established to provide opportunities for both the provincial and district governments and the community, especially weak entrepreneurs in the field of capital, to be able to carry out regional development and develop their businesses, apart from being a source of regional revenue, apart from that PT. Central Java Bank also aims to collect development funds through public savings that are kept in the bank. As a commercial bank like a bank in general, PT. Central Java Bank strives to provide the best service to customers and prospective new customers. Efforts made by PT. The Central Java Bank, among others, simplifies the requirements for applying for credit $^{11}$.

Lending by a Bank must be based on the Bank's confidence in the ability and ability of the debtor to pay off his debt and must be carried out on the basis of sound credit and prudent principles so that the provision of credit does not harm the interests of the Bank, debtor customers and the community of depositing funds, therefore granting of credit must be stated in the form of a credit agreement. A credit agreement is one of the most strategic parts of banking life, because a credit agreement is a media or party intermediary in the relationship between parties who have excess funds / surplus funds with parties who are short of funds and need funds / lack of funds. The real fact is that the provision of credit is a service of the Bank in the life and development of the economy.

In dealing with this lending practice, a prospective customer generally cannot do anything other than approve it because if he does not approve it means that his credit application has failed, while he desperately needs the credit. Credit provided by the Bank contains risks, so in its implementation the Bank always wants to be certain that the credit given is used according to the needs and objectives and can be returned safely. ${ }^{12}$

Therefore, to minimize the risks that will be faced, before extending credit, the Bank must gain confidence in the ability of the debtor customer to repay the credit according to the agreement. Regarding the confidence in the ability of the debtor as referred to in Article 8 paragraph (1) of Act No: 10 of 1998 concerning Banking which

\footnotetext{
${ }^{11}$ Suciani, Fiana Z., \& Witasari, Aryani. (2018). Implementation Of Mudharaba Agreement In PT. State Savings Bank (BTN) Tbk. Sharia Business Unit (SBU) Branch Of Semarang. JURNAL AKTA: Vol. 5, No. 4, 865870.Retrieved from http://jurnal.unissula.ac.id/index.php/akta/article/view/3721

${ }^{12}$ Sri Widodo., Kredit Perbankan, http://katabank.com/kredit-perbankan/, accessed on 19 December 2015
} 
states: "In providing credit or financing based on sharia principles, Commercial Banks are required to have confidence based on in-depth analysis of their intentions and abilities and the ability of the debtor customer to repay the debt or return the financing in accordance with what was agreed "13.

From the elucidation of Article 8 paragraph (1) it can be seen that a Bank's confidence in the ability of its debtor customers is a guarantee in a broad sense, which includes not only immaterial (trust) guarantees, but also guarantees (material collateral). Therefore, in banking practice, Banks usually also require prospective customers / debtors to tie a certain movable or immovable object to be used as collateral in the provision of credit. Although collateral is not an absolute thing in the provision of credit, in reality collateral is a factor commonly considered by Banks because it can be used as debt repayment in the event that a debtor customer is unable to fulfill his obligations to the Bank.

Based on the description of the reasons for choosing the title as mentioned above, several problems can be formulated as follows: How is the implementation of loans made under the hands (without a notary deed) at PT. Central Java Regional Development Bank Semarang Regional Deposit of Sub-Branch? What are the inhibiting factors in the implementation of credit made under hand (without notarial deed) at PT. Central Java Regional Development Bank Semarang Regional Deposit of Sub-Branch, and how are the efforts to solve it?

\section{Research Methods}

This research uses an empirical juridical approach, which is a legal research conducted by examining and analyzing existing facts in line with observations in the field. This type of research is descriptive analytical. Primary data collection method is done by interviewing technique, while secondary data is collected by using literature and documentation methods. Data analysis was carried out by data analysis technique using qualitative descriptive.

\section{Results and Discussion}

\subsection{Execution of loans made under a Notary Hand without a Deed at PT. Central Java} Regional Development Bank Semarang Regional Deposit of Sub-Branch

To get credit at PT. Central Java Bank Sub-Branch Deposit for the Semarang Region, applying for credit must go through the following stages: ${ }^{14}$

a. Credit applications will be given a Loan Application Certificate (SKPP) to be filled in completely and accompanied by the required documents / letters;

\footnotetext{
${ }^{13}$ Chusna, Amalia., \& Hafidz, Jawade. (2019). The Role of the Notary in the Credit Agreement with Mortgage Guarantee (Case Study in the State Savings Bank (Persero) Tbk).JURNAL AKTA: Vol. 6, No. 4, 719726. Retrieved from http://jurnal.unissula.ac.id/index.php/akta/article/view/7668

${ }^{14}$ Interview with Endah Wahyuningsih as the Head of the Central Java Bank, Semarang Regional Deposit Sub-Branch, on January 20, 2016.
} 
b. The "official" credit process begins with the submission of a completed and correct form;

c. All credit applications received will be analyzed and evaluated for credit. A guarantee transaction will be carried out to carry out an examination and research, namely:

1) Credit checks through the Credit Factor 5 ' $C$, The Five C's of, namely: Character; Capacity; Capital; Condition of economic; Collateral / guarantee.

2) Checking the prospective customer's business through: Business examination at the prospective debtor's place to find out and Rate; The conformity between the correctness of the information provided and the contents in the form; The domicile of the prospective debtor; The character of the prospective debtor; Business conditions; Truth assurance and assurance appraisal; Business prospects (production, location, turnover, marketing, etc.); Financial condition (capital requirements, plan to use credit); and Ability to pay credit (income, expenses, profit).

3) Guarantee assessment: Guarantee must have economic value (marketable), including: Can be traded freely; Easy to market; Strategic conditions and location; Does not break quickly; the economic benefits are longer than the credit term of Granted.

4) The guarantee must have juridical power: Not in dispute; There is proof of ownership; Not yet guaranteed to other parties; Eligible to be bound with Mortgage Rights.

d. The results of the analysis and evaluation, the transaction officer will report to the credit provider officer to refuse credit, if the results of the analysis are not worthy of receiving credit or lower the value of the credit application, if the guarantee provided is insufficient with the credit score;

e. Based on the results of the guarantee transaction, the credit provider officer analyzes the credit and the conclusion of the guarantee analysis;

f. The decision on whether to accept credit applications or not is with the leadership of PT. Central Java Bank, Semarang Regional Deposit of Sub-Branch15;

g. From the results of the analysis, a Credit Decree is issued which can be in the form of:

1) Approved: Approval for granting credit occurs because the credit application is considered complete and feasible and the credit limit has been approved by the company leadership according to the prospective customer's type of business. Credit approval will be accompanied by certain conditions, namely: Maximum credit; Credit need; Type of credit; Credit form / nature; Period of time; Provision; Administrative costs; Fine; Insurance; Credit guarantee; Withdrawal.

2) Rejected: Rejection can occur because the requirements requested are incomplete or the guarantee provided is not feasible or because of the wishes of a prospective customers whose credit limit is greater than the amount that PT. Central Java Bank, Semarang Regional Deposit of Sub-Branch.

15 Ibid 
The credit decision that is approved and rejected is then notified to the prospective debtor / credit application. For approved loans accompanied by certain terms above, if the customer ${ }^{16}$ accept the terms given well and want to accept all credit terms from PT. Central Java Bank for the Sub-Branch of the Semarang Regional Deposit, a Credit Agreement (PK) is signed in the form of a credit agreement legalized by a Notary and followed by a perfect mortgage guarantee $(\mathrm{HT})$ in the presence of a Land Deed Maker (PPAT). Then the realization of new credit can be carried out / processed ${ }^{17}$.

\subsection{Inhibiting Factors In Execution of Underhand Loans (Without Notary Deed) At PT.} Central Java Regional Development Bank Semarang Regional Deposit of SubBranch and Settlement Efforts.

In operational activities carried out at PT. Central Java Bank, the Semarang Regional Deposit of Sub-Branch, in the activities of extending credit to the public, there are often obstacles that hinder the implementation of credit disbursement at the bank, although if you pay attention to the implementation of this loan it seems easy, in practice problems often occur related to the implementation of the provision of credit. The credit at PT. Central Java Bank, Semarang Regional Deposit of Sub-Branch.

Problems that often arise, especially from the debtor in terms of filling in agreement forms. As explained above, in order to be able to implement it, apart from having to approve and sign a credit agreement, the debtor is also required to fill out several forms, namely:

a. Application letter applying for credit;

b. Power of attorney;

c. Signature sample card;

d. Statement letter.

In every filling in the form above, every debtor is always emphasized to fill it completely and correctly, but in reality many debtors still think that some forms are not very important, but sometimes only problems that are considered easy and small have fatal consequences for the agreements that have been made.

Apart from what has been stated above according to Hanif Septian Widiantoro is another factor that hinders the implementation of credit extension at PT. Central Java Bank Sub-Branches for Regional Deposit in the Semarang Region are: ${ }^{18}$

a. The factor of providing credit guarantees is in the form of a land certificate, a title of ownership (SHM) or a certificate of building use rights (SHGB) which must be owned by the prospective debtor himself. Many prospective debtors have land assets that are still in the form of meters $C$ and meters $D$ so that the land cannot be pledged as collateral for credit;

\footnotetext{
${ }^{16}$ Ibid

${ }^{17}$ Saputri, Anindia I., \& Witasari, Aryani. (2020). Notary Role In Making The Deed Of Murabahah Financing On Islamic Bank (Review On Financing Agreement In Islamic Bank Of Central Java). JURNAL AKTA: Vol. 7, No. 2, 229-236. Retrieved fromhttp://jurnal.unissula.ac.id/index.php/akta/article/view/7874 18 Ibid.
} 
b. The ability of debtors to pay in installments decreases in line with the increase in basic needs that have not been matched by an increase in income;

c. The occurrence of monetary and economic crises;

d. Changes in interest rates are not well understood by debtors;

e. The habit of paying debtors at the end of the month because they are due in a written credit agreement at the end of the month;

f. The habit of paying installments several months back or not being paid up front. The debtor's business experiences a setback or loss. In this case, the Bank as the creditor is faced with a condition that the debtor is unable to return the principal loan because the debtor's business experiences a setback, loss, sales decline or management error occurs in the debtor's business management;

g. Irregularities in the use of credit or borrowed funds are not used by the debtor for the purpose of the credit application.

Based on the results of the research, it is found that based on the agreement between the debtor and creditor as stated in the credit agreement (Article 7 paragraph (1) there are actions of the debtor which can result in him being declared in default), these actions are: ${ }^{19}$

a. The debtor, within 3 (three) consecutive months, fails to fulfill his obligations to pay principal credit and / or interest, fails to fulfill other obligations as determined in the agreement;

b. The debtor requests to postpone payment (surseance van betaling), is declared bankrupt, taken over, placed under interdiction, or for some reason is no longer entitled to manage and control his assets, either in whole or in part;

c. The debtor violates the provisions and or does not carry out his obligations as agreed on collateral, additional collateral, collateral insurance and housing and house maintenance;

d. Data and / or letters given by the debtor to the Bank are not true / not in accordance with the reality;

e. Debtors are listed in the local black list and are categorized as having nonperforming loans according to Bank Indonesia (BI);

f. The debtor misuses credit or deviates from its purpose.

3.3. Efforts to Settle Inhibiting Factors in Execution of Loans Made Under Hand Without Notary Deed at PT. Central Java Regional Development Bank Semarang Regional Deposit of Sub-Branch

Every bank is bound to face bad credit problems, except for newly established banks. Talking about bad credit is actually talking about the risks that are contained in every provision of credit, thus it can be said that the Bank is unlikely to avoid bad credit. Credit congestion is a matter that causes difficulties for the Bank itself, namely in the form of difficulties, especially concerning the soundness level of the Bank, therefore the Bank is obliged to prevent and anticipate the occurrence of bad credit, or at least the Bank tries to minimize the amount of bad credit so as not to disturb the soundness

${ }^{19}$ Op.Cit. Rizky Amelia Hayusanti. 
level. The bank concerned, the collateral that has been agreed upon can be executed to repay the credit loan, including:

a. The Bank assists in the management of the Property Rights Certificate (SHM) or Building Use Rights Certificate (SHGB) to the National Land Agency (BPN) and continues to provide outreach to candidates when the customer applies for credit, so that there are no obstacles in the implementation of credit at the Bank;

b. Give rights and powers to the Bank (creditors) to get full repayment of the proceeds from the sale of these collateral, if the customer (debtor) makes a breach of contract, that is, does not pay back his debt at the time stipulated in the Credit Agreement (PK);

c. Guarantee that the debtor participates in transactions to finance his business, so that the possibility of leaving his business at his own expense for the company can be prevented or at least the possibility of doing so is minimized;

d. Give encouragement to debtors to fulfill credit agreements. In particular regarding the repayment in accordance with agreed terms so that he does not lose the wealth that has been pledged to the Bank.

As for what is being done at PT. Central Java Bank, Semarang Regional Deposit of SubBranch, handling bad credit. that is, preferring the deliberation route or negotiating in advance in overcoming bad debts that occur. The method taken by PT. Central Java Bank, Semarang Regional Deposit of Sub-Branch, to handle credit congestion to a minimum, namely by: ${ }^{20}$

a. Rescheduling (rescheduling), namely changes in credit terms concerning the payment schedule and / or time period;

b. Reconditioning, namely changes in part or all of the credit terms which are not limited to changes in payment schedules, time periods, and / or other requirements as long as they do not involve changes in the maximum credit balance;

c. Restructuring ie changes in credit terms in the form of: additional Bank funds and / or; conversion of all or part of credit into new loan principal; and conversion of all or part of the credit into participation in the company, which is accompanied by rescheduling and / or terms of return. Settlement in this way is an alternative step before settlement is carried out through a more judicial institution.

\section{Closing}

Execution of loans made under hand (without notary deed) at PT. Central Java Regional Development Bank Semarang Regional Deposit of Sub-Branch Credit application forms will be given a Loan Application Certificate (SKPP) to be filled in completely and accompanied by the required documents / letters. The "official" credit process begins with submitting the form that has been filled in completely and correctly, all credit applications received will be Credit analysis and evaluation are carried out, the guarantee transaction is carried out, the guarantee transaction is carried out to conduct an examination and research, then the results of the analysis and evaluation,

\footnotetext{
20 lbid.
} 
the transaction officer will report to the credit provider officer to refuse credit, if the analysis results are not suitable for receiving credit or reduce the value of the credit application, if the guarantee is given insufficient credit score. Based on the results of the guarantee transaction, the credit provider officer analyzes the credit and the conclusion from the analysis is the adequacy of the guarantee, and for the credit decision whether or not the credit application is accepted is the leader, from the results of the analysis a Credit Decree is issued which is the basis for making a Credit Agreement made by the Bank. For the government, owners or shareholders of PT. The Central Java Regional Development Bank, Semarang Regional Deposit of Sub-Branch, in this case gives flexibility and freedom to the Bank Management to professionally decide credit policies independently according to business intuition, so that decisions on credit applications have actually gone through analysis and creditworthiness assessment adequate in accordance with Bank management standards and for banks to attract public interest in utilizing credit facilities provided by PT. Central Java Regional Development Bank, Semarang Regional Deposit of Sub-Branch, so in this case the Bank should carry out promotions as much as possible so that it is expected that public awareness of the importance of credit facilities for the development of their business and when the agreement opens a credit agreement between the Bank and the debtor both parties should also regulate or agree on the joint determination of the selling price of the goods to be used as collateral.

\section{References}

\section{Journals:}

[1] Chusna, Amalia., \& Hafidz, Jawade. (2019). The Role of the Notary in the Credit Agreement with Mortgage Guarantee (Case Study in the State Savings Bank (Persero) Tbk).JURNAL AKTA: Vol. 6, No. 4, 719-726.Retrieved from http://jurnal.unissula.ac.id/index.php/akta/article/view/7668

[2] Rachmawati, Noor., \& Hanim, Lathifah. (2018). Notary Role in The Establishment of Foreign Investment Limited Company Based on The Act No. 25 Of 2007 on Investment in Semarang.JURNAL AKTA: Vol. 5, No. 4, 965-974.Retrieved from http://jurnal.unissula.ac.id/index.php/akta/article/view/3939

[3] Saputri, Anindia I., \& Witasari, Aryani. (2020). Notary Role In Making The Deed Of Murabahah Financing On Islamic Bank (Review On Financing Agreement In Islamic Bank Of Central Java). JURNAL AKTA: Vol. 7, No. 2, 229-236. Retrieved fromhttp://jurnal.unissula.ac.id/index.php/akta/article/view/7874

[4] Suciani, Fiana Z., \& Witasari, Aryani. (2018). Implementation Of Mudharaba Agreement In PT. State Savings Bank (BTN) Tbk. Sharia Business Unit (SBU) Branch Of Semarang.JURNAL AKTA: Vol. 5, No. 4, 865-870.Retrieved from http://jurnal.unissula.ac.id/index.php/akta/article/view/3721

\section{Books:}

[1] Aman, Mgs. Edy. J. (1989). Kredit Perbankan Suatu Tinjauan Yuridis. Yogyakarta: Liberty 
[2] Badrulzaman, Mariam Darus. (1983). Perjanjian Kredit Bank. Bandung: Alumni

[3] Badrulzaman, Mariam Darus. (1994). Aneka Hukum Bisnis. Bandung: Alumni

[4] Fuady, Munir. 2002. Hukum Tentang Pembiayaan Dalam Teori dan Praktek. Bandung: Citra Aditya Bakti

[5] Hay, Marhainis Abdul. (1979). Hukum Perbankan Di Indonesia. Jakarta: Pradnya Paramita

[6] Ignatius Ridwan Widyadharma, 1995, Hukum Perbankan, CV Ananta, Semarang

[7] Prodjodkoro, Wirdjono. (1981). Pokok-pokok Hukum Perdata Tentang Persetujuanpersetujuan Tertentu. Bandung: Sunan Gunungjati

[8] Sembiring, Sentosa. (2012). Hukum Perbankan. Jakarta: CV. Mandar Maju

\section{Regulations:}

[1] The Constitution of the Republic of Indonesia of 1945

[2] The Civil Code

[3] Law of the Republic of Indonesia Number 10 of 1998 concerning Amendments to Law of the Republic of Indonesia Number 7 of 1992 concerning Bank

[4] Law of the Republic of Indonesia Number 23 of 1999 concerning Bank Indonesia

[5] Law of the Republic of Indonesia Number 21 of 2011 concerning the Financial Services Authority

[6] Presidential Regulation of the Republic of Indonesia No. 9 of 2009 concerning Financing Institutions

\section{Website:}

Sri Widodo., Kredit Perbankan, http://katabank.com/kredit-perbankan/,

Interview:

Interview with Endah Wahyuningsih as the Head of the Central Java Bank, Semarang Regional Deposit Sub-Branch. 